\title{
A novel putative member of the family Benyviridae is associated with soilborne wheat mosaic disease in Brazil
}

\author{
J. B. Valente ${ }^{a}$, F. S. Pereira ${ }^{a}$, L. A. Stempkowski ${ }^{a}$, M. Farias ${ }^{a}$, P. Kuhnem ${ }^{b}$, D. Lau ${ }^{c}$, \\ T. V. M. Fajardo ${ }^{d}$, A. Nhani Junior ${ }^{\mathrm{e}}$, R. T. Casa $^{\mathrm{a}}$, A. Bogo ${ }^{\mathrm{a}}$ and F. N. da Silva ${ }^{\mathrm{a} *}$ (D) \\ ${ }^{a}$ Crop Production Graduate Program, Santa Catarina State University/UDESC, Lages, SC 88520-000; ' Biotrigo Genética, Passo Fundo, RS \\ 99052-160; 'Embrapa Trigo, Passo Fundo, RS 99050-970; ' Embrapa Uva e Vinho, Bento Gonçalves, RS 95701-008; and ${ }^{\circledR} E m b r a p a$ \\ Informática Agropecuária, Campinas, SP 13083-886, Brazil
}

Soilborne wheat mosaic disease (SBWMD), originally attributed to infections by Soilborne wheat mosaic virus (SBWMV) and Wheat spindle streak mosaic virus (WSSMV), is one of the most frequent virus diseases and causes economic losses in wheat in southern Brazil. This study aimed to characterize molecularly the viral species associated with wheat plants showing mosaic symptoms in Brazil. Wheat leaves and stems displaying mosaic symptoms were collected from different wheat cultivars in Passo Fundo municipality, Rio Grande do Sul State, southern Brazil. Double-stranded RNA was extracted and submitted to cDNA library synthesis and next-generation sequencing. No sequences of SBWMV and WSSMV were detected but the complete genome sequence of a putative new member of the family Benyviridae was determined, for which the name wheat stripe mosaic virus (WhSMV) is proposed. WhSMV has a bipartite genome with RNA 1 and RNA 2 organization similar to that of viruses belonging to Benyviridae. WhSMV RNA 1 has a single open reading frame (ORF) encoding a polyprotein with putative viral replicase function. WhSMV RNA 2 has six ORFs encoding the coat protein, the major protein (read-through), triple gene block movement proteins (TGB 1, 2 and 3) and ORF 6 (hypothetical protein). In addition to the genomic organization and nucleotide and amino acid sequence identities, phylogenetic analyses also corroborated that WhSMV is a virus species of the Benyviridae. However, isolates of WhSMV formed a clade distinct from members of the genus Benyvirus. It was also demonstrated that the plasmodiophorid Polymyxa graminis is associated with wheat roots showing SBWMD symptoms and infected by WhSMV.

Keywords: Benyviridae, mosaic symptoms, next-generation sequencing, Polymyxa graminis, Triticum aestivum, wheat stripe mosaic virus

\section{Introduction}

Wheat (Triticum spp.) belongs to the family Poaceae and is one of the most cultivated cereals globally. The Triticum aestivum species, known as common wheat, is heavily cultivated and responsible for over $80 \%$ of world wheat production. In Brazil, wheat is grown during the winter and spring, mainly in the three southern states: Paraná (PR), Santa Catarina (SC) and Rio Grande do Sul (RS). These states together accounted for $85 \%$ of the total Brazilian wheat produced during the 2017 season (Companhia Nacional de Abastecimento, 2018).

Viral diseases are important factors impeding the management of wheat crops in Brazil and can cause serious damage and losses. Yellow dwarf disease together with soilborne wheat mosaic disease (SBWMD) are the most common viral diseases and can cause significant losses in wheat fields in southern Brazil (Lau, 2014). Yellow

*E-mail: fabio.silva@udesc.br

Published online 3 January 2019 dwarf disease is caused by a number of related viruses, such as Barley yellow dwarf virus-PAV (BYDV-PAV, Luteovirus, Luteoviridae) and Cereal yellow dwarf virusRPV (CYDV-RPV, Polerovirus, Luteoviridae; Caetano, 1972; Mar et al., 2013); SBWMD is attributed to Soilborne wheat mosaic virus (SBWMV, Furovirus, Virgaviridae; Caetano et al., 1971, 1978) and Wheat spindle streak mosaic virus (WSSMV, Bymovirus, Potyviridae; Caetano, 1998). In southern Brazil, under ideal conditions such as wet and compacted soil and with temperatures near to $15{ }^{\circ} \mathrm{C}$, SBWMD induces yield reductions to the wheat crop of over $50 \%$ (Barbosa et al., 2001). In an assay carried out in an area infested with the plasmodiophorid Polymyxa graminis and with a history of SBWMD, Dalbosco et al. (2002b) verified a reduction in grain weight per plant from $7 \%$ to $56 \%$ in wheat and from $51 \%$ to $59 \%$ in triticale, depending on the genotype. In the 1000-grain weight, the decrease varied from $4 \%$ to $26 \%$ in wheat and from $23 \%$ to $30 \%$ in triticale (Dalbosco et al., 2002b).

Caetano et al. (1971) described that SBWMD had been seen in the southern states of Brazil since the 1970s 
and that SBWMV was its causal agent. The diagnosis of SBWMV was based on mechanical transmission tests, in vitro physical properties, particle morphology and ultrastructural aspects of affected plant tissues (Caetano et al., 1978). However, these diagnostic methods are subjective and prone to error. Nowadays in Brazil, the detection of the aetiological agent of SBWMD is still based on observation of the symptoms and viral particles. In addition, the use of antisera or primers designed from viral sequences from other countries has only resulted in negative reactions in the diagnostic tests, suggesting that the SBWMV and WSSMV isolates found in Brazil could be divergent from other regions or that a species not yet characterized is associated with SBWMD in Brazil. Next-generation sequencing (NGS) is an appropriate tool for the characterization of viral species associated with SBWMD, especially because there is a possibility of mixed infections and differences in nucleotide sequences of the viral populations associated with wheat fields in Brazil. A metagenomic approach may also detect the presence of viral species not yet characterized.

The presence of $P$. graminis in the roots of wheat plants with SBWMD symptoms has been reported in Brazil by Caetano et al. (1971), Pierobom et al. (1972) and Dalbosco et al. (2002a). Polymyxa graminis is an obligate root parasite of several temperate grasses and represents a significant threat to agriculture due to its ability to transmit viruses of agronomic importance, including SBWMV. Polymyxa graminis is responsible for the transmission of at least 14 plant viruses belonging to the Furovirus, Bymovirus, Pecluvirus and Benyvirus genera (Adams \& Jacquier, 1994).

Currently, the family Benyviridae includes four species, Beet necrotic yellow vein virus (BNYVV), Beet soilborne mosaic virus (BSBMV), Burdock mottle virus (BdMV) and Rice stripe necrosis virus (RSNV), all of the genus Benyvirus, and two tentative species, Mangifera indica latent virus (MILV) and Hubei beny-like virus 1 (HBBLV; Gilmer et al., 2017). The genome of members of the genus Benyvirus is composed of at least two polyadenylated positive-sense single-strand (ss) RNA molecules of approximately 7 and $4.6 \mathrm{~kb}$ (Bouzoubaa et al., 1986, 1987; Kiguchi et al., 1996; Saito et al., 1996). The betterknown members of the genus Benyvirus are transmitted by the root-infecting vectors Polymyxa betae and P. graminis (Tamada et al., 1996; Morales et al., 1999).

The main objective of this study was to characterize molecularly the viral species associated with wheat plants showing SBWMD symptoms and to determine whether the plasmodiophorid $P$. graminis is associated with wheat roots exhibiting SBWMD symptoms and infected by the detected viral species.

\section{Materials and methods}

\section{Sample collection for NGS analysis}

Leaves and stems of wheat ( $T$. aestivum) with typical mosaic symptoms (Fig. 1) were collected in Embrapa Trigo in Passo
Fundo municipality, Rio Grande do Sul state, southern Brazil where, historically, field trials were carried out to assess the susceptibility and resistance of wheat cultivars to SBWMD (Rio Grande do Sul State Assay). In this area the infected plants are known to contain typical particles (rod-shaped) of the SBWMV described by Caetano et al. (1978). Samples, including leaves and stems, from each of the eight cultivars (Karl 92, Everest, OR 1, CEP 11, TBIO Toruk, TBIO Tibagi, Esporão and LG Oro) were collected and stored in a freezer $\left(-80^{\circ} \mathrm{C}\right)$.

\section{Double-stranded RNA extraction}

Extraction of double-stranded RNA (dsRNA) was performed as described by Valverde et al. (1990) with some modifications. Some samples with SBWMD symptoms did not have sufficient vegetative tissue; thus, two mixed samples were generated (TBIO Toruk and TBIO Tibagi, Esporão and LG Oro).

Samples of $30 \mathrm{~g}$ wheat tissue were ground with liquid nitrogen and incubated with $129 \mathrm{~mL}$ extraction buffer $(90 \mathrm{~mL} 2 \times$ sodium chloride-Tris-EDTA buffer (STE); $35 \mathrm{~mL} \mathrm{10 \%} \mathrm{sodium}$ dodecyl sulphate (SDS); $2 \mathrm{~mL}$ bentonite $\left(45 \mathrm{mg} \mathrm{mL}^{-1}\right) ; 2 \mathrm{~mL}$ $\beta$-mercaptoethanol) for $5 \mathrm{~min}$ in a shaker at room temperature. After adding $35 \mathrm{~mL}$ of Tris-HCl-saturated phenol (pH 8.0) and $35 \mathrm{~mL}$ chloroform:isoamyl alcohol $(24: 1 \mathrm{v} / \mathrm{v})$ to the solution, samples were incubated for a further $1 \mathrm{~h}$. The solution was centrifuged $\left(16274 \mathrm{~g}\right.$ ) for $10 \mathrm{~min}$ at $4{ }^{\circ} \mathrm{C}$, and the resulting supernatant (nucleic acid solution) was enriched for dsRNA using Whatman CF11 cellulose affinity chromatography. Three cycles of centrifugation and one cycle of cellulose chromatography, all of them using $1 \times$ STE buffer with $17 \%$ ethanol $(\mathrm{v} / \mathrm{v})$ for resuspending the cellulose pellet or washing the column, were used to remove residual ssRNA. The sediment cellulose was collected and resuspended after each centrifugation. After the third centrifugation cycle, the resuspended cellulose was transferred into a column and washed. The dsRNA was eluted with $1 \times$ STE buffer, precipitated, centrifuged and resuspended. Subsequently, the dsRNA was cleaned using a RNeasy Plant Mini kit (QIAGEN), following the manufacturer's protocol.

The purity and concentration of the dsRNA were measured by spectrophotometry (NanoDrop 2000; Thermo Scientific). The dsRNA samples were placed in RNA Stable tubes (Biomatrica) and dried in a Speed Vac (Eppendorf Concentrator Plus) for $1.5 \mathrm{~h}$; NGS was performed at Macrogen Inc.

\section{NGS and bioinformatic analyses}

NGS sequencing reads were generated from a complementary DNA library (cDNA) using the Illumina HiSeq 2500 platform (Macrogen Inc.). Adapters and low-quality reads were removed by Trimmomatic (Bolger et al., 2014). The NGS data were initially analysed using the TRINITY tool (Grabherr et al., 2011) for RNASeq assembly. The resulting contigs were analysed for similarity to records in public databases (GenBank). Sequences homologous to the wheat genome were removed in order to analyse only those with viral origin. NGS reads that did not map to the wheat genome were again submitted to genome assembly with TRINITY and, in parallel, with VELVET (Zerbino \& Birney, 2008). The results were compared using CAP3 (Huang \& Madan, 1999) in two stages. In the first stage, the contigs resulting from the initial assemblies of TRINITY and VELVET were analysed individually. In the second stage, the contigs resulting from the first step were again grouped and analysed. The results showed that the VELVET-mounted contigs were contained in those derived from the TRINITY assembly. The contigs were 

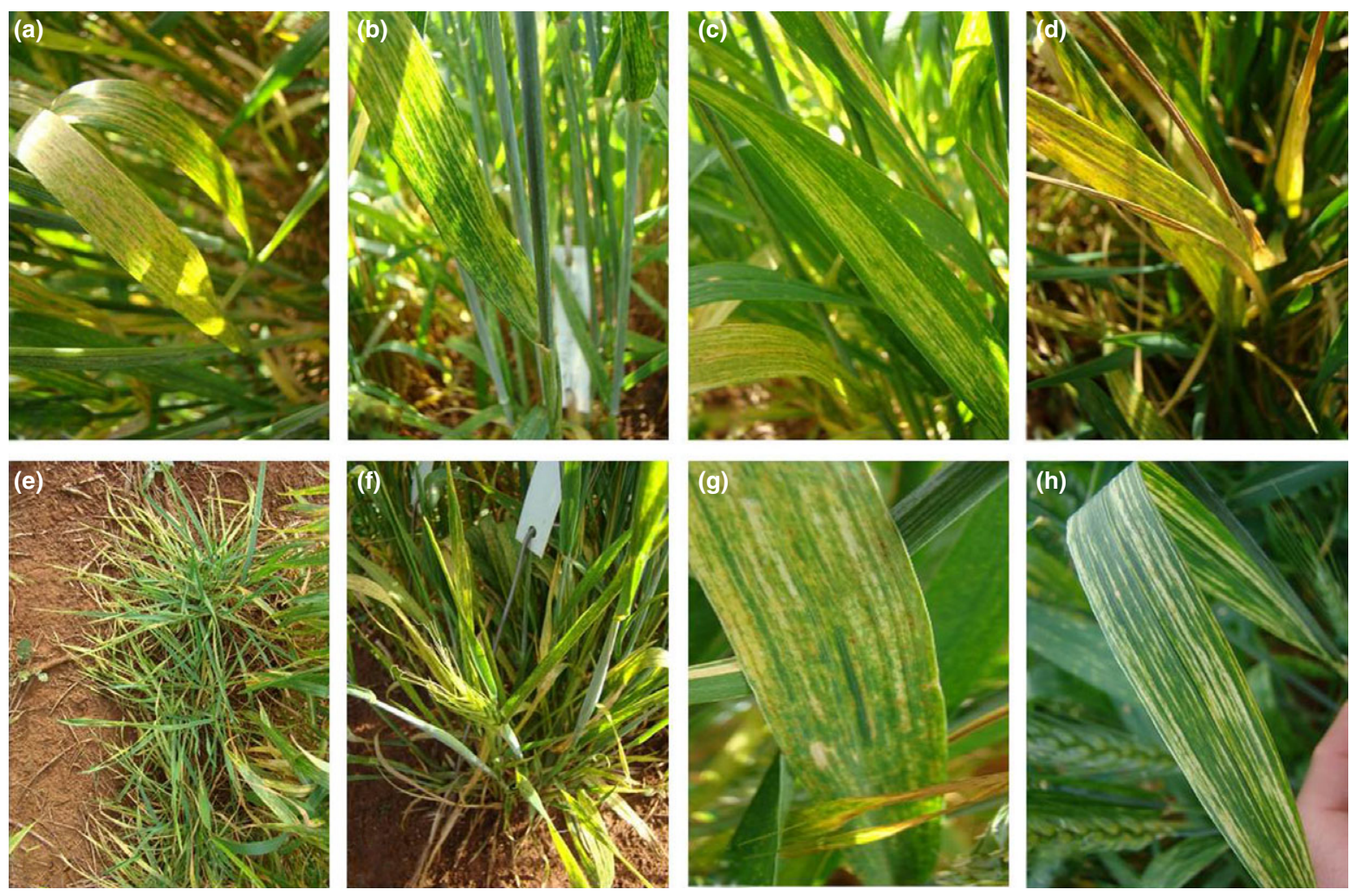

Figure 1 Mosaic symptoms in different wheat cultivars (Triticum aestivum) infected with wheat stripe mosaic virus (WhSMV). (a-h) Wheat cultivars CEP 11, Esporão, LG ORO, Everest, Karl 92, OR1, TBIO Toruk and TBIO Tibagi, respectively.

subsequently compared with the NCBI database using the BLASTN and BLASTX search tools with standard parameters.

\section{RT-PCR protocol}

For cDNA synthesis, $100 \mathrm{ng}$ purified dsRNA was denatured at $94{ }^{\circ} \mathrm{C}$ for 5 min followed by cDNA synthesis using the oligo dT and the ImProm II Reverse Transcription System kit (Promega), in accordance with the manufacturer's recommendations. The PCR mixture contained $5 \mu \mathrm{L}$ cDNA (c. $1 \mu \mathrm{g}), 10 \mu \mathrm{L}$ of $5 \times$ PCR buffer, $2 \mu \mathrm{L} \mathrm{MgCl}_{2}(25 \mathrm{~mm}), 1 \mu \mathrm{L}$ of dNTP $(10 \mathrm{~mm}), 1 \mu \mathrm{L}$ of 0.25 Go Taq DNA polymerase $\left(5 \mathrm{U}^{-1}\right.$; Promega) and ultrapure water to a final volume of $50 \mu \mathrm{L}$. Reaction conditions were $94{ }^{\circ} \mathrm{C}$ for $2 \mathrm{~min}$; 34 cycles of $94{ }^{\circ} \mathrm{C}$ for $1 \mathrm{~min}, 42-54{ }^{\circ} \mathrm{C}$ (depending on the primer used, Table 1) for $1 \mathrm{~min}$, and $72{ }^{\circ} \mathrm{C}$ for $1 \mathrm{~min}$; and a final extension at $72{ }^{\circ} \mathrm{C}$ for $10 \mathrm{~min}$. The amplified fragments were subjected to $1 \%$ agarose gel electrophoresis, stained with GelRed (Biotium), visualized under a UV light transilluminator, and photographed. PCR fragments were purified using the Gene Jet kit (Fermentas), in accordance with the manufacturer's recommendations, and sequenced (Helixxa Genomic Services).

\section{Sequence analysis and phylogeny}

The contigs were submitted to open reading frame (ORF) prediction using the ORF FINDER program (NCBI, https://www.ncbi. nlm.nih.gov/orffinder/). The identification of conserved and functional domains of proteins was performed using the SMART tool (http://smart.embl-heidelberg.de/). Phylogenetic trees were constructed using the maximum likelihood method implemented in the MEGA v. 6.0 program (Tamura et al., 2013) with Tamura's three-parameter model, gamma distribution $(\mathrm{G})$, and invariant sites (I). The robustness of each internal branch was estimated from 2000 bootstrap replicates for the coat protein (CP) and for the triple gene block movement 1 (TGB 1) genes, and from 6000 bootstrap replicates for the replicase gene. The alignments used for the phylogenetic analyses were performed using the MUSCLE tool available in MEGA v. 6.0.

Nucleotide and amino acid identity analyses were performed with multiple sequence alignment (https://www.ebi.ac.uk/Tools/ $\mathrm{msa} / \mathrm{muscle} /$ ), using the complete genome sequences and coding regions of the species described in the family Benyviridae and the isolates characterized in this study.

\section{Vector detection and characterization}

Wheat roots of the cultivars TBIO Toruk and BRS Guamirim were collected at the Embrapa Trigo experimental station in Passo Fundo municipality, Rio Grande do Sul state, southern Brazil. Ten plants with symptoms from each cultivar were collected and the roots were pooled separately.

Wheat roots were washed in running water, dried in filter paper and prepared for visualization of $P$. graminis structures. The roots were immersed in a solution containing $10 \mathrm{~mL}$ lactic acid $(85-90 \%), 20 \mathrm{~mL}$ glycerol $(99.5 \%), 10 \mathrm{~mL}$ distilled water, $10 \mathrm{~g}$ crystallized phenol, and $0.5 \mathrm{~g}$ blue cotton dye and heated to $100{ }^{\circ} \mathrm{C}$. Microscope slides were prepared and the $P$. graminis structures were visualized under an optical microscope at $\times 400$ magnification. 
Table 1 Primers used for NGS validation and detection of WhSMV.

\begin{tabular}{|c|c|c|c|c|c|}
\hline Set & Name & Sequence $\left(5^{\prime}-3^{\prime}\right)$ & Position alignment (nt) & Annealing temperature $\left({ }^{\circ} \mathrm{C}\right)$ & Amplicon length (bp) \\
\hline \multirow[t]{2}{*}{1} & Beny_CP $(F)$ & AAGTGTCGCAAGCTTCGCG & 89 & 54 & 641 \\
\hline & Beny_CP (R) & ATCGCACCGACGTAAGAACT & 730 & & \\
\hline \multirow[t]{2}{*}{2} & Beny_TGB2 (F) & AAGAGTTGTATGCGATGTTGG & 3967 & 52 & 607 \\
\hline & Beny_TGB2 (R) & CGTCTTGTCGGCGTAAAAGGT & 4574 & & \\
\hline \multirow[t]{2}{*}{3} & Beny_Pol (F) & ATCGATGCTGACGCTTTCACTG & 3770 & 54 & 465 \\
\hline & Beny_Pol (R) & ACGAAACACCTGTGTCGCTA & 4234 & & \\
\hline \multirow[t]{2}{*}{4} & Beny_1_3'-UTR & AGTGAGCGTTGTCACTCGTCCG & 6243 & 42 & c. 357 \\
\hline & Oligo $(\mathrm{dT})_{15}$ & TTTTTTTTTTTTTTT & - & & \\
\hline \multirow[t]{2}{*}{5} & Beny_2_3'-UTR & ACGAAAGTCGTCGGTTTT & 4572 & 42 & c. 329 \\
\hline & Oligo $(d T)_{15}$ & TTTTTTTTTTTTTTTT & - & & \\
\hline
\end{tabular}

NGS, next-generation sequencing; WhSMV, wheat stripe mosaic virus; CP, coat protein; Pol, polymerase (replicase); TGB, triple gene block; UTR, untranslated region.

Molecular identification of $P$. graminis was carried out using rDNA as a target. The partial nuclear 5.8S rRNA gene and internal transcribed spacer 1 (ITS1) were amplified by PCR from root samples collected from each cultivar. The washed and dried roots were ground with liquid nitrogen. Total DNA extraction using $100 \mathrm{mg}$ powdered root tissues was performed in accordance with the protocol described by Doyle \& Doyle (1987), followed by PCR using the primers Pgfwd2/Pxrev7 (Ward \& Adams, 1998). The PCR mixture consisted of $1 \mu \mathrm{L}$ DNA (100 ng), $5 \mu \mathrm{L}$ of $5 \times$ buffer, $2 \mu \mathrm{L} \mathrm{MgCl}_{2}(25 \mathrm{~mm}), 0.5 \mu \mathrm{L}$ dNTPs $(10 \mathrm{~mm}), 5 \mu \mathrm{L}$ each primer $(10 \mathrm{~mm}), 0.25 \mu \mathrm{L}$ Taq DNA polymerase $\left(5 \mathrm{U} \mu \mathrm{L}^{-1}\right.$; Promega) and ultrapure water to a final volume of $25 \mu \mathrm{L}$. PCR conditions were in accordance with the work of Tyagi et al. (2016). The amplified fragments were subjected to electrophoresis in 1\% agarose gel, stained with GelRed (Biotium), visualized under UV light, and photographed. PCR fragments were purified using the Gene Jet kit (Fermentas), in accordance with the manufacturer's recommendations, and Sanger sequencing was performed using the primers Pgfwd2/Pxrev7 (Helixxa Genomic Services). The sequences were compared with sequences from the database available in GenBank. A phylogenetic tree was constructed using the maximum likelihood method implemented in MEGA v. 6.0, using Kimura's two-parameter model with invariant sites (I). The robustness of each internal branch was estimated from 1000 bootstrap replicates. The alignments used for the phylogeny were performed with the MUSCLE tool available in MEGA v. 6.0.

To determine the presence of the virus in root samples, total RNA extraction from the previously described root pool of the TBIO Toruk and BRS Guamirim cultivars was performed using the AxyPrep Multisource Total RNA Miniprep kit (Axygen Biosciences), in accordance with the manufacturer's recommendations. The presence of the virus was determined following the RT-PCR protocol described above and using primers for amplification of the $\mathrm{CP}$ gene.

\section{Virus incidence}

Additional samples of 13 wheat cultivars (Everest, Karl 92, OR 1, CEP 11, BRS Pastoreio, BRS Reponte, Esporão, TBIO Itaipu, TBIO Toruk, ORS 1401, LG Oro, BRS Guamirim and Amplitude) were collected in four areas from southern Brazil. All the collected samples presented typical symptoms of SBWMD. From Rio Grande do Sul state, in Coxilha $\left(28^{\circ} 04^{\prime} 53.2^{\prime \prime} \mathrm{S}, 52^{\circ} 24^{\prime} 55.8^{\prime \prime}\right.$ W), Passo Fundo $\left(28^{\circ} 13^{\prime} 40^{\prime \prime} \mathrm{S}, 52^{\circ} 24^{\prime} 30^{\prime \prime} \mathrm{W}\right)$ and Santo Augusto $\left(27^{\circ} 54^{\prime} 04.20^{\prime \prime} \mathrm{S}, 53^{\circ} 49^{\prime} 44.53^{\prime \prime} \mathrm{W}\right)$ municipalities, 3,11 and 3 samples, respectively, were collected. In Paraná state, nine samples from Ivaiporã municipality $\left(24^{\circ} 19^{\prime} 51.8^{\prime \prime} \mathrm{S}, 51^{\circ} 45^{\prime} 20.9^{\prime \prime} \mathrm{W}\right)$ were collected. The 26 samples were stored in a freezer $\left(-80^{\circ} \mathrm{C}\right)$ until processing. Total RNA extraction from each sample was performed using the AxyPrep Multisource Total RNA Miniprep kit (Axygen Biosciences), in accordance with the manufacturer's recommendations. The presence of the virus characterized in this study was determined following the RT-PCR protocol described above using Beny_TGB2 primers (Table 1).

\section{Results}

\section{NGS and genome assembly}

Double-strand RNA from leaves and stems of six wheat samples with symptoms (cultivars Karl 92, Everest, OR 1, CEP 11, TBIO Toruk and TBIO Tibagi, Esporão and LG Oro) was extracted and submitted to cDNA library synthesis and NGS analysis. The Illumina HiSeq 2500 platform generated approximately 30 million reads for each analysed sample. The samples yielded a large number of reads, considering the total number of sequenced bases, total number of reads, and CG/AT content analysed. This large number of reads was expected and the quality parameters (Q20) were higher than 99\%, indicating excellent NGS quality (data not shown).

TRINITY software generated 127665 contigs (1023 contigs homologous to viral sequences) and VELVET generated 43353 contigs (393 contigs homologous to viral sequences). The complete genome sequence of a putative novel species of the Benyviridae was obtained from all wheat samples analysed when the contig data were compared with already well-characterized viral species. No further reads and/or contigs of other viral species were found and the results indicated that only the novel species reported was present in the analysed samples.

The genome of the putative new virus species was composed of two RNA segments (RNA 1 and RNA 2; Fig. 2). The data indicated that the genomic organization of the characterized virus was very similar to those of members of the family Benyviridae. RNA 1 was the largest segment and varied in length from 6583 to $6600 \mathrm{nt}$, depending on the isolate and excluding the poly-A tail. The 5'- and $3^{\prime}$-UTR regions were $115 \mathrm{nt}$ and 336-353 nt 

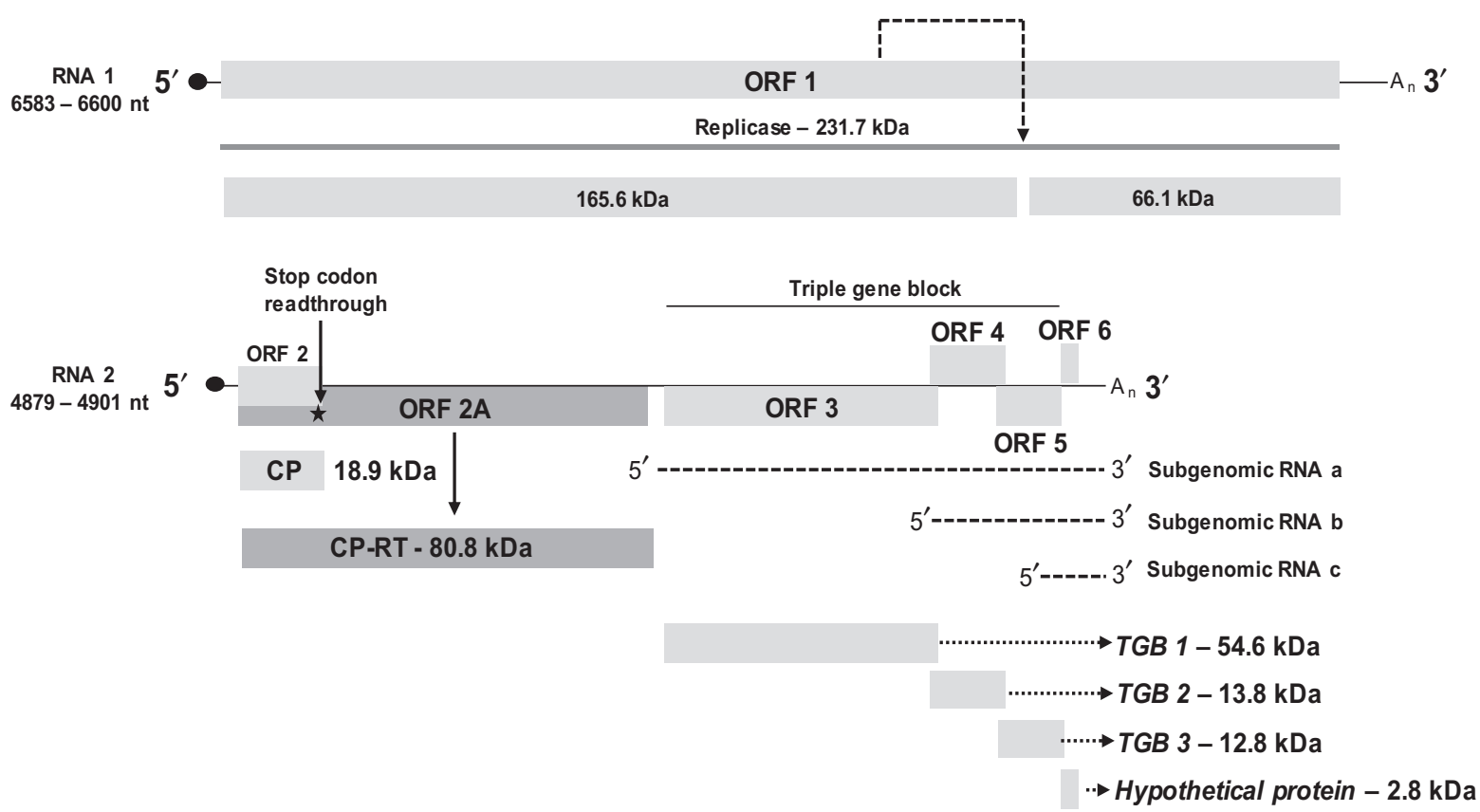

Figure 2 Genome organization and putative translation strategies of Wheat stripe mosaic virus (WhSMV). The scheme indicates putative selfcleavage of the replicase protein (black arrow RNA 1), a read-through stop codon UAG (black star RNA 2), putative m7Gppp (black circle) and the $3^{\prime}$ poly (A)-tails $\left(A_{n}\right)$. The WhSMV has seven predicted open reading frames (ORFs): ORF 1 encodes putative viral replicase, ORF 2 encodes putative coat protein, ORF 2A encodes putative read-through domain, ORF 3 encodes putative triple gene block 1 (TGB 1), probably coded from subgenomic RNA a, ORF 4 encodes putative TGB 2, probably coded from subgenomic RNA b, ORF 5 encodes putative TGB 3, probably coded from subgenomic RNA b, and ORF 6 hypothetical protein, probably coded from subgenomic RNA c. Predicted molecular weights of proteins are indicated in kilodaltons $(\mathrm{kDa})$. Dotted lines are used for all putative aspects.

in size, respectively, for all characterized isolates (Table 2). RNA 1 had a single ORF with the potential to encode a $231.7 \mathrm{kDa}$ polyprotein with putative viral replicase function. The polyprotein of the novel virus was possibly autocleaved into two proteins of $165.6 \mathrm{kDa}$ and $66.1 \mathrm{kDa}$ (Fig. 2) and contained methyltransferase, helicase (Hel), papain-like protease and RNA-dependent RNA polymerase (RdRP) motifs. A conserved motif (Gly-Asp-Asp), which is the signature of all viral RdRPs, was present in the replicase at position 1863-1865 aa of all of the characterized viral isolates. The RNA 2 segment ranged in length from 4879 to 4901 nt (Table 2), excluding the poly-A tail. The 5'- and 3 '-UTR regions of RNA 2 were $145 \mathrm{nt}$ and 96-116 nt in size, respectively, for all characterized isolates (Table 2). Six putative ORFs were identified in RNA 2 of the new virus (Table 2; Fig. 2). ORF 2 encoded the $18.9 \mathrm{kDa} \mathrm{CP}$ that had a stop codon (UAG). When this codon was translated by readthrough protein strategies, an $80.8 \mathrm{kDa}$ read-through (RT) protein (encoded from ORF 2A) could be produced (Fig. 2). In the RT protein, the VTER (Val-Thr-Glu-Arg) motif was found at amino acid positions 638-641 for WhSMV:BR:Everest, WhSMV:BR:Karl92 and WhSMV: BR:OR1; for WhSMV:BR:CEP11 and WhSMV:BR: Esporão-Oro, the amino acid positions were 640-643. ORFs 3, 4 and 5 comprised the putative triple gene block (TGB), associated with viral movement in plants (Fig. 2). ORF 3 (putative TGB 1) encoded a $54.6 \mathrm{kDa}$ protein with a helicase domain. ORF 4 (putative TGB2) encoded a $13.8 \mathrm{kDa}$ protein, which has a conserved domain associated with viral movement. ORF 5 (putative TGB 3) encoded a $12.8 \mathrm{kDa}$ protein and ORF 6 encoded a hypothetical $2.8 \mathrm{kDa}$ protein.

\section{NGS validation}

In order to confirm that the putative virus was not an artefact of NGS sequencing, five primers pairs were designed to the different genomic regions (Table 1), based on the sequence analysis. All primer sets provided amplicons in all six samples analysed and they were sequenced (capillary sequencing/Sanger; Fig. S1). Analysis of these sequences showed $99-100 \%$ identity with the sequences obtained by NGS. In addition, the use of the primer sets 4 and 5 (Table 1) was essential to confirm the accuracy of the NGS in obtaining the $3^{\prime}$ ends of RNAs 1 and 2, respectively, because fragments of the expected size and nucleotide sequences were obtained.

These results confirmed the presence of the new putative virus in the wheat samples showing mosaic symptoms used for NGS.

\section{Sequence analysis}

The determined genome sequences of the viral isolates were deposited in GenBank (accession numbers 


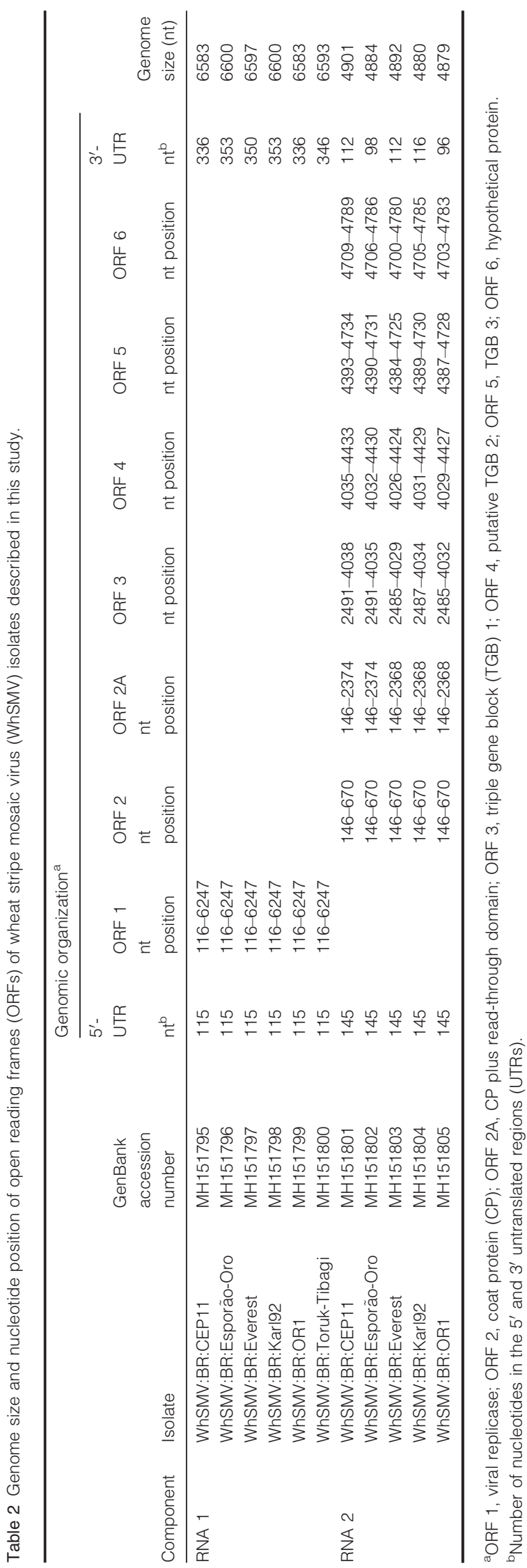

MH151795-MH151805). The nucleotide identity of RNA 1 and RNA 2 among Brazilian isolates varied from $97 \%$ to $99 \%$, indicating that all of them were isolates from the same viral species (Fig. 3). Sequence analysis indicated significant nucleotide and amino acid identity of Brazilian isolates with species of the family Benyviridae. When the Brazilian isolates, characterized in this study, were compared with the viruses belonging to the Benyviridae, low nucleotide identity was observed, varying from $48 \%$ to $51 \%$ and $42 \%$ to $47 \%$ for RNA 1 and RNA 2, respectively (Fig. 3). The Brazilian isolates showed highest identities for both RNA 1 and RNA 2 to BNYVV and BSBMV. When excluding the sequences of the Brazilian isolates, the nucleotide identities of RNA 1 and RNA 2 ranged from $52 \%$ to $78 \%$ and $45 \%$ to $70 \%$, respectively among the species of the Benyviridae (Fig. 3).

Analysis of the coding regions revealed that the nucleotide and amino acid sequence identities among the viral isolates characterized here were $98-99 \%$ for ORF $1,95-100 \%$ for ORF 2, 97-99\% for ORF 2A, 96$100 \%$ for ORF 3, 99-100\% for ORF 4, and 96-100\% for ORF 5 (Fig. 3). ORF 6 presented 100\% nucleotide and amino acid identity among the Brazilian isolates but was not compared with the other species of the family Benyviridae due to differences in size. ORF 1 of the Brazilian isolates shared $53-57 \%$ nucleotide identity with other species of the Benyviridae (Fig. 3), and ORF $2,2 \mathrm{~A}, 3,4$ and 5 shared nucleotide identities of 48 $53 \%, 42-47 \%, 46-51 \%, 48-57 \%$ and $49-52 \%$, respectively with other members of the Benyviridae (Fig. 3). In general, the amino acid identities were lower than those observed for nucleotides (Fig. 3).

Based on the genomic organization and the nucleotide and amino acid sequences analysed in the viral isolates described in this work, it is proposed that the virus found infecting different wheat cultivars in Brazil could be considered a new putative species in the family Benyviridae. For this species, the name Wheat stripe mosaic virus is proposed.

\section{Phylogenetic analysis}

Phylogenetic trees were generated using the nucleotide sequences of the CP, replicase and TGB 1 genes, which verified the relationship of WhSMV to viruses of the family Benyviridae (Fig. 4). However, WhSMV isolates formed a distinct clade from the species of the genus Benyvirus, with strong bootstrap support (Fig. 4). The topology observed in the phylogenetic trees suggested that WhSMV does not belong to the genus Benyvirus. The Brazilian isolates formed a monophyletic group for all coding regions used (Fig. 4), indicating close relationships among them.

The phylogeny of complete RNA 1 and RNA 2 showed that the WhSMV isolates were closely related (Fig. S2), confirming the results of analysis of the coding regions and supporting that they are all of the same species. Additionally, phylogenetic analyses suggested that 
RNA 1

\begin{tabular}{|c|c|c|c|c|c|c|c|}
\hline & \multicolumn{6}{|c|}{ 1. WhSMV-1 } \\
\hline 2. WhSMV-2 & 98 & & & & & & \\
\hline 3. WhSMV-3 & 98 & 99 & & & & & \\
\hline 4. WhSMV-4 & 98 & 99 & 99 & & & & \\
\hline 5. WhSMV-5 & 99 & 99 & 99 & 99 & & & \\
\hline 6. WhSMV-6 & 99 & 99 & 99 & 99 & 99 & & \\
\hline 7. MILV & 48 & 48 & 48 & 48 & 48 & 48 & \\
\hline 8. RSNV & 49 & 49 & 50 & 49 & 49 & 4952 & \\
\hline 9. BdMV & 49 & 49 & 49 & 49 & 49 & 495254 & \\
\hline 10. BNYVV & 50 & 51 & 51 & 51 & 50 & 515455 & 559 \\
\hline \multirow[t]{2}{*}{ 11. BSBMV } & 49 & 50 & 50 & 50 & 50 & 505355 & 55978 \\
\hline & [1] & [2] & [3] & [4] & [5] & [6] [7] [8 & {$[9][10][11]$} \\
\hline
\end{tabular}

\section{ORF 1}

\begin{tabular}{|lllllllllllll|}
\hline 1. WhSMV-1 & & 99 & 99 & 99 & 99 & 99 & 37 & 36 & 34 & 36 & 35 \\
2. WhSMV-2 & 98 & & 99 & 99 & 99 & 99 & 37 & 36 & 34 & 36 & 35 \\
3. WhSMV-3 & 98 & 99 & & 99 & 99 & 99 & 37 & 36 & 34 & 36 & 35 \\
4. WhSMV-4 & 99 & 99 & 99 & & 99 & 99 & 37 & 36 & 34 & 36 & 35 \\
5. WhSMV-5 & 99 & 99 & 99 & 99 & & 99 & 37 & 36 & 34 & 36 & 35 \\
6. WhSMV-6 & 99 & 99 & 99 & 99 & 99 & & 37 & 36 & 34 & 36 & 35 \\
7. MILV & 55 & 55 & 55 & 55 & 55 & 55 & & 42 & 41 & 43 & 41 \\
8. RSNV & 57 & 57 & 57 & 57 & 57 & 57 & 51 & & 44 & 45 & 44 \\
9. BdMV & 55 & 55 & 55 & 55 & 55 & 55 & 51 & 52 & & 54 & 52 \\
10. BNYVV & 53 & 54 & 54 & 54 & 54 & 54 & 51 & 53 & 56 & & 84 \\
11. BSBMV & 53 & 53 & 53 & 53 & 53 & 53 & 52 & 53 & 57 & 74 \\
& {$[1]$} & {$[2]$} & {$[3]$} & {$[4]$} & {$[5]$} & {$[6]$} & {$[7]$} & {$[8]$} & {$[9][10][11]$} \\
\end{tabular}

\section{ORF 2A}

\begin{tabular}{|llllllllll|}
\hline 1. WhSMV-1 & & 98 & 99 & 99 & 99 & 20 & 20 & 19 & 21 \\
2. WhSMV-2 & 97 & & 98 & 99 & 99 & 20 & 20 & 20 & 21 \\
3. WhSMV-3 & 99 & 97 & & 99 & 99 & 20 & 20 & 19 & 21 \\
4. WhSMV-4 & 98 & 98 & 98 & & 99 & 20 & 20 & 19 & 20 \\
5. WhSMV-5 & 99 & 99 & 99 & 99 & & 20 & 20 & 20 & 20 \\
6. RSNV & 42 & 42 & 42 & 42 & 42 & & 24 & 22 & 23 \\
7. BdMV & 43 & 43 & 43 & 43 & 43 & 45 & & 26 & 25 \\
8. BNYVV & 46 & 45 & 46 & 45 & 46 & 50 & 49 & & 56 \\
9. BSBMV & 46 & 46 & 47 & 47 & 47 & 47 & 49 & 65 & \\
& {$[1]$} & {$[2]$} & {$[3]$} & {$[4]$} & {$[5]$} & {$[6]$} & {$[7]$} & {$[8]$} & {$[9]$}
\end{tabular}

\section{ORF 4}

\begin{tabular}{|lccccccccccc|}
\hline 1. WhSMV-1 & & 100 & 100 & 100 & 99 & 28 & 39 & 35 & 38 & 40 \\
2. WhSMV-2 & 99 & & 100 & 100 & 99 & 28 & 39 & 35 & 38 & 40 \\
3. WhSMV-3 & 99 & 99 & & 100 & 99 & 28 & 39 & 35 & 38 & 40 \\
4. WhSMV-4 & 100 & 99 & 99 & & 99 & 28 & 39 & 35 & 38 & 40 \\
5. WhSMV-5 & 99 & 99 & 99 & 99 & & 24 & 23 & 27 & 28 & 26 \\
6. MILV & 49 & 48 & 48 & 48 & 48 & & 31 & 33 & 29 & 30 \\
7. RSNV & 54 & 54 & 54 & 54 & 53 & 47 & & 37 & 47 & 46 \\
8. BdMV & 55 & 55 & 55 & 55 & 55 & 54 & 54 & & 51 & 53 \\
9. BNYVV & 51 & 51 & 51 & 51 & 51 & 51 & 57 & 57 & & 82 \\
10. BSBMV & 57 & 57 & 57 & 57 & 57 & 51 & 57 & 58 & 76 \\
& {$[1]$} & {$[2]$} & {$[3]$} & {$[4]$} & {$[5]$} & [6] & {$[7]$} & {$[8]$} & {$[9][10]$}
\end{tabular}

RNA 2

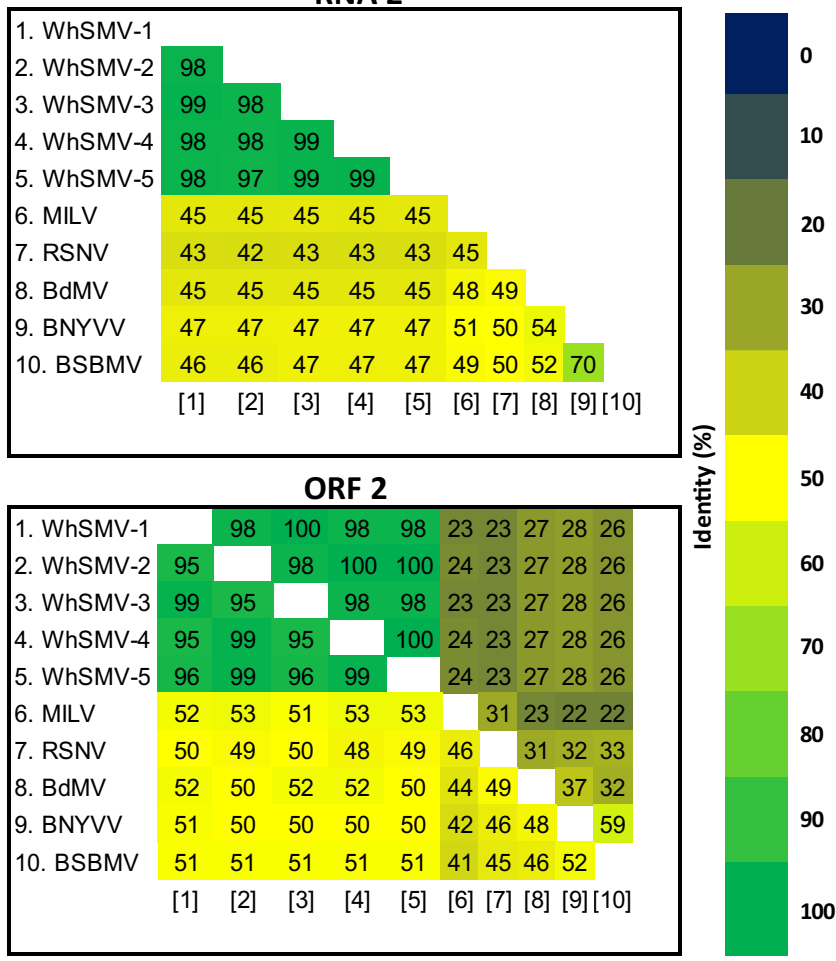

ORF 3

\begin{tabular}{|c|c|c|c|c|c|c|c|c|c|c|}
\hline 1. WhSMV-1 & & 99 & 97 & 96 & 96 & 22 & 26 & 26 & 30 & 29 \\
\hline 2. WhSMV-2 & 98 & & 97 & 96 & 96 & 22 & 26 & 26 & 30 & 29 \\
\hline 3. WhSMV-3 & 98 & 97 & & 99 & 99 & 22 & 26 & 26 & 30 & 29 \\
\hline 4. WhSMV-4 & 97 & 96 & 99 & & 100 & 22 & 26 & 26 & 30 & 29 \\
\hline 5. WhSMV-5 & 97 & 96 & 99 & 99 & & 22 & 26 & 26 & 30 & 29 \\
\hline 6. MILV & 49 & 49 & 49 & 49 & 49 & & 29 & 29 & 26 & 26 \\
\hline 7. RSNV & 46 & 46 & 47 & 46 & 46 & 40 & & 42 & 38 & 38 \\
\hline 8. BdMV & 49 & 49 & 49 & 49 & 49 & 44 & 48 & & 48 & 46 \\
\hline 9. BNYVV & 51 & 51 & 51 & 51 & 51 & 46 & 54 & 55 & & 75 \\
\hline 10. BSBMV & 49 & 49 & 49 & 49 & 48,7 & 45 & 53 & 52 & 73 & \\
\hline & [1] & [2] & [3] & [4] & [5] & & & [8] & & [10] \\
\hline
\end{tabular}

ORF 5

\begin{tabular}{|l|c|c|c|c|c|c|c|c|c|}
\hline 1. WhSMV-1 & & 100 & 100 & 100 & 100 & 28 & 28 & 28 & 21 \\
2. WhSMV-2 & 100 & & 100 & 100 & 100 & 28 & 28 & 28 & 21 \\
3. WhSMV-3 & 100 & 100 & & 100 & 100 & 28 & 28 & 28 & 21 \\
4. WhSMV-4 & 100 & 100 & 100 & & 100 & 28 & 28 & 28 & 21 \\
5. WhSMV-5 & 96 & 96 & 96 & 96 & & 28 & 28 & 28 & 21 \\
6. RSNV & 52 & 52 & 52 & 52 & 51 & & 26 & 26 & 37 \\
7. BdMV & 49 & 49 & 49 & 49 & 47 & 50 & & 34 & 31 \\
8. BNYVV & 50 & 50 & 50 & 50 & 49 & 55 & 53 & 68 \\
9. BSBMV & 51 & 51 & 51 & 51 & 51 & 58 & 50 & 71 & \\
& {$[1]$} & {$[2]$} & {$[3]$} & {$[4]$} & {$[5]$} & {$[6]$} & {$[7]$} & {$[8]$} & {$[9]$}
\end{tabular}

Figure 3 Two-dimensional plot representing the percentage sequence identities among isolates of wheat stripe mosaic virus (WhSMV) and species of the family Benyviridae for RNA 1, RNA 2, and all open reading frames (ORFs), except ORF 6. Percentage nucleotide and amino acid sequence identities are shown below and above the diagonal, respectively. ORF 1 encodes viral replicase, ORF 2 encodes coat protein, ORF 2A encodes read-through domain, ORF 3 encodes triple gene block 1 (TGB 1), ORF 4 encodes TGB 2, and ORF 5 encodes TGB 3. Members of the family Benyviridae are Beet necrotic yellow vein virus (BNYVV), Beet soil-borne mosaic virus (BSBMV), Burdock mottle virus (BdMV), Rice stripe necrosis virus (RSNV), and Mangifera indica latent virus (MILV). [Colour figure can be viewed at wileyonlinelibrary.com]. 
Wheat stripe mosaic virus is a new species within the family Benyviridae and distinct from the other species of the genus Benyvirus.

\section{Characterization of the plasmodiophorid associated with wheat roots}

Members of the family Benyviridae are transmitted by parasites of the root system belonging to the order Plasmodiophorales. The presence of this vector in the wheat roots was confirmed by optical microscopy and it was possible to visualize the encysted zoospores (Fig. 5a) and the formation of zoosporangia (Fig. 5b) in both BRS Guamirim and TBIO Toruk cultivars.

To support the morphological data, parts of the analysed roots were used for detection and molecular characterization of the putative vector, as well as the detection of WhSMV. Using specific primers for the nuclear $5.8 \mathrm{~S}$ rRNA gene and ITS1 and for the coding region of WhSMV CP, it was possible to amplify DNA fragments of the expected size for P. graminis (c. 240 and $310 \mathrm{bp}$ ) and WhSMV (641 bp) from the root samples of the two cultivars analysed (Fig. 5c). The DNA fragments of P. graminis obtained from wheat cultivars BRS Guamirim and TBIO Toruk in this study showed nucleotide identity of $98 \%$ among themselves and $100 \%$ among the isolates from BRS Guamirim (GenBank no. MH318570) and isolates from Belgium (GenBank no. AM259278) and the United Kingdom (GenBank no. AJ841287). Polymyxa graminis from wheat cultivar TBIO Toruk (GenBank no. MH318569) showed nucleotide identity of $99 \%$ with isolates from the Czech Republic (GenBank LT221860) and Australia (GenBank KF535921). The DNA fragments from the WhSMV CP amplification were also sequenced and showed nucleotide identity higher than $99 \%$ with the WhSMV isolates characterized in this work.

Phylogenetic analysis of the nuclear 5.8S rRNA gene and ITS1 supported the classification of the plasmodiophorid found in the wheat roots as $P$. graminis. Isolates from different countries and hosts formed two distinct groups but there was no division by host or geographical region (Fig. $5 \mathrm{~d}$ ). The two isolates of $P$. graminis characterized here are in different groups. Together, the results of the morphological, molecular and phylogenetic characterizations indicated the association of $P$. graminis with roots of wheat plants with mosaic symptoms infected by WhSMV in Brazil.

\section{Prevalence of the new virus in different production areas}

To verify the presence of the new virus in different areas, 26 samples of wheat were collected with symptoms in four different municipalities from southern Brazil. RTPCR and electrophoretic analyses indicated the presence of WhSMV in all samples analysed (Fig. S3). Ivaiporã is $452 \mathrm{~km}$ away from Santo Augusto and Passo Fundo municipalities and $436 \mathrm{~km}$ away from Coxilha. These results indicate the association of the new virus characterized here with SBWMD in different wheat crop areas in Brazil.

\section{Discussion}

The viruses SBWMV and WSSMV have been reported as the causal agents of SBWMD in Brazil, based mainly on the viral particle morphology (Caetano et al., 1978; Lau, 2014). In fact, electron microscopy analyses carried out in 1978 (Caetano et al., 1978) and in 2015 (D. Lau, Embrapa Trigo, Passo Fundo, Brazil, personal communication) indicated the presence of rod-shaped virions of two different sizes, having the same particle morphology as expected for the WhSMV described here. In the present investigation, these two viruses were not present in the wheat plants showing mosaic symptoms. No reads of the SBWMV and WSSMV were detected in the NGS analysis. For the deep sequencing in this study, dsRNAs were used as templates and it is known that RNA viruses form dsRNA either as their encapsidated genome or during the process of replication. In metagenomic studies of plant viruses, the use of purified dsRNA has facilitated in-depth analyses of viruses from different families (Roossinck et al., 2015), supporting the accuracy of the result in the present study that only WhSMV infected the wheat samples analysed.

Members of the family Benyviridae have two to five segments of positive-sense ssRNA (Gilmer et al., 2017). The viral isolates described here showed two RNA segments, equal to the number for BdMV, RSNV and MILV (Lozano \& Morales, 2009; Kondo et al., 2013; Sela et al., 2016). However, the type species of the genus Benyvirus, BNYVV, presented four or five RNA segments (Kiguchi et al., 1996; Saito et al., 1996) and BSBMV had four RNA segments (Heidel et al., 1997). No contigs were found that corresponded to viral genomic segments other than the RNA 1 and RNA 2 of benyviruses.

The 5'-UTR of WhSMV RNA 1 (115 nt) was similar in length to that of members of the genus Benyvirus (124-153 nt; Bouzoubaa et al., 1987; Lee et al., 2001; Lozano \& Morales, 2009; Kondo et al., 2013). However, the 3'-UTR of WhSMV (336-353 nt) was larger than that found in members of the genus Benyvirus (181-233 nt; Lee et al., 2001; Lozano \& Morales, 2009; Kondo et al., 2013).

RNA 1 of WhSMV encodes a $231.7 \mathrm{kDa}$ polyprotein with putative viral replicase function and has a similar size to that observed for members of the genus Benyvirus (Saito et al., 1996; Lee et al., 2001; Lozano \& Morales, 2009; Kondo et al., 2013). Proteolytic cleavage of the replicase has been described for members of the family Benyviridae and distinguishes this group from all other viruses with rod-shaped particles (Gilmer et al., 2017). The peptidase domain (papain-like proteinase) is involved in cleavage of the viral polyprotein (Hehn et al., 1997). A conserved GDD motif (Gly-Asp-Asp) is present in all WhSMV isolates and is also present in the same position within Benyviridae members (Bouzoubaa et al., 1987; Poch et al., 1989; Lee et al., 2001; Lozano \& Morales, 2009). 

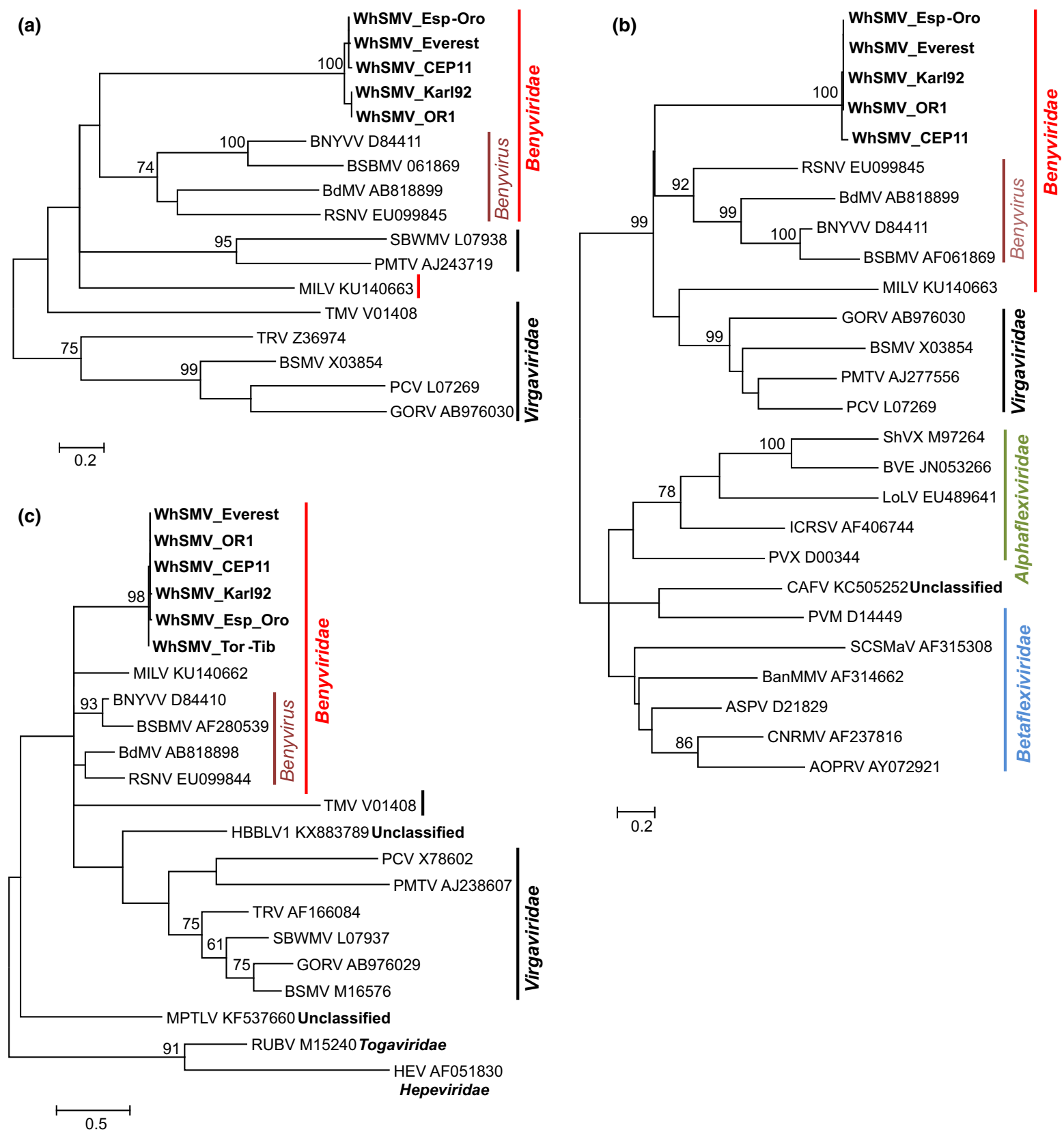

Figure 4 Phylogenetic relationships, based on the codon-aligned nucleotide sequences of coat protein (a), replicase (b), and first triple gene block (c) of viruses of the family Benyviridae and other related viruses. Numbers on branches indicate bootstrap values. Alignments were performed with MUSCLE. Bars indicate the number of substitutions per site. Members of the family Benyviridae are Wheat stripe mosaic virus (WhSMV), Beet necrotic yellow vein virus (BNYVV), Beet soil-borne mosaic virus (BSBMV), Burdock mottle virus (BdMV), Rice stripe necrosis virus (RSNV), and Mangifera indica latent virus (MILV). Other viruses are: AOPRV, African oil palm ringspot virus; ASPV, Apple stem pitting virus, BanMMV, Banana mild mosaic virus; BSMV, Barley stripe mosaic virus; BVE, Blackberry virus E; CAFV, Cassava alphaflexivirus; CNRMV, Cherry necrotic rusty mottle virus; GORV, Gentian ovary ringspot virus; HBBLV, Hubei beny-like virus 1; HEV, Human hepatitis E virus; ICRSV, Indian citrus ringspot virus; LoLV, Lolium latent virus; MPTLV, Macrophomina phaseolina tobamo-like virus; PCV, Peanut clump virus; PMTV, Potato mop top virus; PVM, Potato virus M; PVX, Potato virus X; RUBV, Rubella virus; SBWMV, Soil-borne wheat mosaic virus; SCSMaV, Sugarcane striate mosaic-associated virus; ShVX, Shallot virus X; TMV, Tobacco mosaic virus; and TRV, Tobacco rattle virus. Bars displayed on the right side of the trees correspond to families and genera of viruses. [Colour figure can be viewed at wileyonlinelibrary.com]

The length of the RNA 2 of WhSMV (4879-4901 nt) was similar to that of members of the genus Benyvirus (4314-4635 nt; Bouzoubaa et al., 1986; Lee et al., 2001;
Lozano \& Morales, 2009; Kondo et al., 2013). The 5'UTR of WhSMV RNA 2 (145 nt) was also similar in length to that of members of the genus Benyvirus (144- 

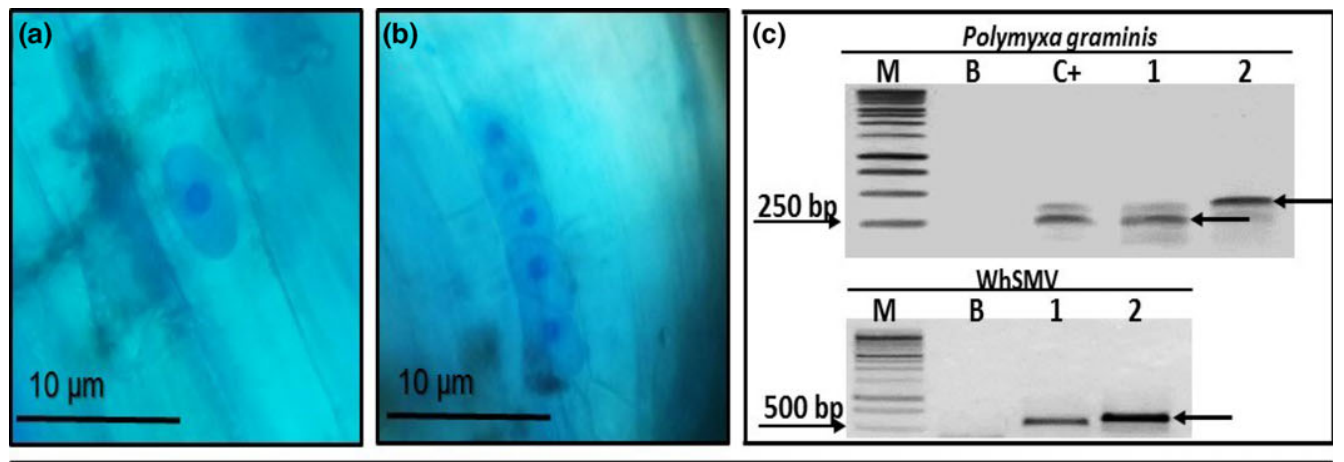

(d)

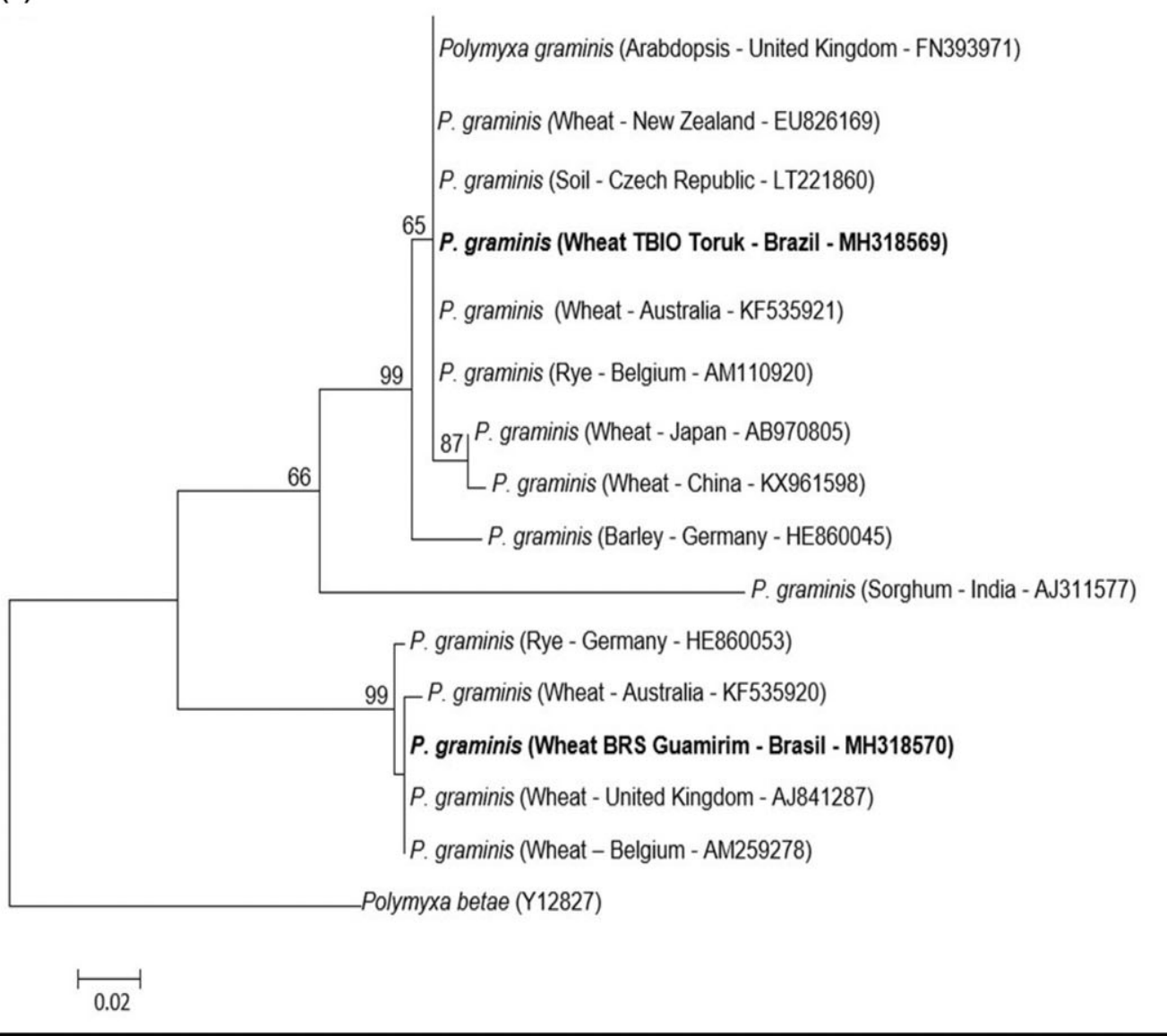

Figure 5 Different stages and characterization of the vector Polymyxa graminis in wheat roots (cultivars TBIO Toruk and BRS Guamirim) infected by wheat stripe mosaic virus (WhSMV). (a) Encysted zoospore in infected wheat root hair. (b) Formation of zoosporangium in infected wheat root hair. (c) Electrophoretic analyses for molecular detection of $P$. graminis and WhSMV in cultivars TBIO Toruk (1) and BRS Guamirim (2). M, molecular markers, 1 kb DNA ladder; C+, total DNA and RNA from wheat roots infected by P. graminis (for $P$. graminis and WhSMV detection); B, blank (water). The arrows indicate the purified and sequenced PCR fragments. (d) Maximum likelihood tree obtained from the alignment of the partial nuclear 5.8S rRNA and internal transcribed spacer 1 (ITS1) ribosomal DNA sequences of $P$. graminis, including Brazilian isolates characterized in this study (in bold) as well as additional P. graminis sequences from GenBank. Numbers on branches indicate bootstrap values (1000 replications). The host, country and accession numbers of the sequences are presented in the phylogenetic tree. Polymyxa betae was used as an out-group. [Colour figure can be viewed at wileyonlinelibrary.com].

179 nt; Bouzoubaa et al., 1986; Lee et al., 2001; Lozano \& Morales, 2009; Kondo et al., 2013). However, the 3'UTR of WhSMV RNA 2 (96-116 nt) was smaller than those of of BNYVV, BdMV, BSBMV and RSNV
(189-227 nt; Bouzoubaa et al., 1986; Lee et al., 2001; Lozano \& Morales, 2009; Kondo et al., 2013).

Six putative ORFs were identified in RNA 2 of the new virus, as also observed for RNA 2 of BNYVV, 
BSBMV and RSNV (Bouzoubaa et al., 1986; Lee et al., 2001; Lozano \& Morales, 2009). ORF 2 encodes the viral CP responsible for protecting the genetic material and for long-distance movement. The KTER (Lys-ThrGlu-Arg) motif found in the RT protein of BNYVV, BSBMV and RSNV is required for virus transmission by P. betae and P. graminis (Tamada et al., 1996; Lozano \& Morales, 2009). A similar motif (VTER) was found in the amino acid sequences of the WhSMV. The involvement of the VTER motif in transmission by $P$. graminis of the new virus isolates characterized here needs to be verified.

ORFs 3, 4 and 5 comprise the putative triple gene block (TGB) associated with viral movement in plants. Putative TGB 1 (encoded from ORF 3) of the new virus isolates has a helicase domain, also found in BdMV, BNYVV and MILV (Peltier et al., 2008; Kondo et al., 2013; Sela et al., 2016). The putative TGB 2 encoded from ORF 4 has a conserved domain associated with viral movement, as described for BdMV (Kondo et al., 2013). ORF 5 encodes a putative TGB 3 protein, like the other members of the family Benyviridae. These proteins are important for cell-to-cell and long-distance movement of the virus in plants infected with BNYVV (Gilmer et al., 1992). Given the similarities found and the conserved domains, it is suggested that the TGB discovered in isolates of the new virus is involved in cell-to-cell movement. The size of ORF 6 was the most divergent among the characterized isolates and species of the Benyviridae. The protein encoded by ORF 6 has been reported to be associated with the suppression of gene silencing (Chiba et al., 2013). The function of the hypothetical protein encoded by ORF 6 of WhSMV should be verified. The TGB and the hypothetical protein are probably expressed by subgenomic RNAs, which characterize the viruses of the Benyviridae (Gilmer et al., 2017).

The current taxonomic criterion used for species demarcation in the genus Benyvirus is amino acid sequence identity of CP $<90 \%$ (Gilmer et al., 2017). Based on the genomic organization and the nucleotide and amino acid sequences identified in the viral isolates described in this work, it is proposed that wheat stripe mosaic virus can be considered a new putative species of the family Benyviridae.

Phylogenetic analyses indicated that WhSMV isolates formed a distinct clade when trees were constructed employing complete RNA segments and all used coding regions, indicating a close relationship among Brazilian isolates; this corroborates the sequence analysis data and supports the idea that the viral isolates described here belong to the same species and are distinct from other species of the genus Benyvirus.

An important biological feature of members of the Benyviridae is their transmission by parasites of the root system. BNYVV and BSBMV were reported to be transmitted by $P$. betae (Tamada et al., 1996). RSNV was detected infecting rice in the Rio Grande do Sul State and was transmitted by P. graminis (Morales et al., 1999). The presence of $P$. graminis in the wheat roots of TBIO
Toruk and BRS Guamirim cultivars has also been confirmed in the present investigation. The morphological structures found correspond to those described for P. graminis by Ledingham (1939) and are similar to those observed by Tyagi et al. (2016), who analysed the roots of barley and observed the different phases of the $P$. graminis life cycle. The primer pair Pgfwd2/Pxrev7 is specific for $P$. graminis and amplification using this primer pair resulted in amplified fragments of the expected sizes $310 \mathrm{bp}$ and $240 \mathrm{bp}$ (Ward \& Adams, 1998). Nucleotide identity and phylogenetic analyses of these DNA sequences supported the classification of the plasmodiophorid found in the wheat roots as $P$. graminis.

Phylogenetic analysis also indicated that the two isolates of $P$. graminis characterized in this study are in different groups, supporting the nucleotide differences found. These differences were expected, because molecular studies revealed high variability of $P$. graminis (Legreve et al., 2002). Another recent study in China using the ITS region of $P$. graminis ribosomal DNA from 63 samples of wheat roots indicated considerable variation of the sequences (Xu et al., 2018). The morphological, molecular and phylogenetic characterization indicated the association of $P$. graminis with roots of wheat plants infected by WhSMV in Brazil and suggested that WhSMV could be transmitted by P. graminis.

The dataset obtained in this study indicates that the aetiological agent of SBWMD in Brazil is a distinct virus. It cannot be ruled out that SBWMV and other viruses occur in wheat in Brazil. However, at present, the most probable hypothesis is that the virus described by Caetano et al. (1978) is in fact the new species described here and that, using the tools available in the 1970s, accurate diagnosis was not possible. This hypothesis is corroborated by the fact that numerous researchers who attempted to characterize and detect Brazilian isolates in recent years with primers and antiserum for SBWMV obtained negative results. In addition, the association between WhSMV and wheat plants with SBWMD of different cultivars and areas was demonstrated. The WhSMV was detected in different wheat cultivars in four different areas (Coxilha, Passo Fundo, Santo Augusto and Ivaiporã municipalities), confirming the presence of the virus described here in all the 26 wheat samples with mosaic symptoms collected.

This new virus is so distinct from other already described viruses infecting wheat that an exciting hypothesis and/or questions about its origin are raised. In future work, it will be necessary to characterize isolates from other geographic regions and other hosts in an attempt to decipher its evolutionary history. Is it a virus that came with wheat to Brazil and then evolved in this country? Alternatively, is it a native virus that acquired the ability to infect wheat? The virus might infect other grasses and alternative hosts and further studies should be carried out to test this possibility. The fact that it is a virus transmitted by a soilborne microorganism and, therefore, has population dynamics slower than that of airborne pathogens, may have preserved populations that contain steps in the evolution of this virus. 


\section{Acknowledgements}

This work was supported by Biotrigo Genética and Embrapa (02.16.04.037.00.00). J.B.V., F.S.P. and L.A.S. are Brazilian Federation for Support and Evaluation of Graduate Education (CAPES) fellows. The authors thank Embrapa Informática Agropecuária for support in the bioinformatic analyses and Dr Altamir Frederico Guidolin for the use of his laboratory. The authors are also grateful to two anonymous referees and the editor Dr Anders Kvarnheden for suggestions that have improved the manuscript.

\section{References}

Adams MJ, Jacquier C, 1994. Infection of cereals and grasses by isolates of Polymyxa graminis (Plasmodiophorales). Annals of Applied Biology $125,53-60$.

Barbosa MM, Goulart LR, Prestes AM, Juliatti FC, 2001. Genetic control of resistance to Soilborne wheat mosaic virus in Brazilian cultivars of Triticum aestivum L. Thell. Euphytica 122, 417-22.

Bolger AM, Lohse M, Usadel B, 2014. Trimmomatic: a flexible trimmer for Illumina sequence data. Bioinformatics 30, 2114-20.

Bouzoubaa S, Ziegler V, Beck D, Guilley H, Richards K, Jonard G, 1986. Nucleotide-sequence of beet necrotic yellow vein virus RNA-2. Journal of General Virology 67, 1689-700.

Bouzoubaa S, Quillet L, Guilley H, Jonard G, Richards K, 1987. Nucleotide-sequence of beet necrotic yellow vein virus RNA-1. Journal of General Virology 68, 615-26.

Caetano VR, 1972. Estudo sobre o Virus do Nanismo Amarelo da Cevada, em Trigo, no Rio Grande do Sul. Piracicaba, Brazil: Escola Superior de Agricultura 'Luiz de Queiroz', Universidade de São Paulo, $\mathrm{PhD}$ thesis.

Caetano VR, 1998. O impacto das doenças do trigo transmitidas por vetores. Correio Agrícola 1, 16-9.

Caetano VR, Pierobom CR, Luzzardi CG, Prestes AM, 1971. Mosaico do trigo começa a causar problemas. Indicação da Pesquisa XIII. Inst. Pesq. Agropec. Sul. DNPEA, Ministério da Agricultura, 1-2.

Caetano VR, Kitajima EW, Costa AS, 1978. Ocorrência e estudos electrono-microscópicos do vírus do mosaico do trigo, transmitido pelo solo, no estado do Rio Grande do Sul. Fitopatologia Brasileira 3, $39-46$.

Chiba S, Hleibieh K, Delbianco A et al., 2013. The benyvirus RNA silencing suppressor is essential for long-distance movement, requires both zinc-finger and NoLs basic residues but not a nucleolar localization for its silencing-suppression activity. Molecular PlantMicrobe Interactions 26, 168-81.

Companhia Nacional de Abastecimento, 2018. A cultura do trigo. [http://www.conab.gov.br/OlalaCMS/uploads/arquivos/17_05_03_16_ 09_46_a_cultura_do_trigo_versao_digital_nova_logo.pdf]. Accessed 14 January 2018.

Dalbosco M, Schons J, Prestes AM, 2002a. Incidência e índice de doença do mosaico do trigo em cereais de inverno e em gramíneas de verão, associados ao Polymyxa graminis. Fitopatologia Brasileira 27, 48-52.

Dalbosco M, Schons J, Prestes AM, Cecchetti D, 2002b. Effects of Soilborne wheat mosaic virus on yield in wheat and triticale cultivars. Fitopatologia Brasileira 27, 53-7.

Doyle JJ, Doyle JL, 1987. A rapid DNA isolation procedure for small quantities of fresh leaf tissue. Phytochemical Bulletin 19, 11-5.

Gilmer D, Ratti C, ICTV Report Consortium, 2017. ICTV Virus Taxonomy Profile: Benyviridae. Journal of General Virology 98, 1571-2.

Gilmer D, Bouzoubaa S, Hehn A, Guilley H, Richards K, Jonard G, 1992. Efficient cell-to-cell movement of Beet necrotic yellow vein virus requires $3^{\prime}$ proximal genes located on RNA 2. Virology 189, 40-7.
Grabherr MG, Haas BJ, Yassour M et al., 2011. Trinity: reconstructing a full-length transcriptome without a genome from RNA-Seq data. Nature Biotechnology 29, 644-52.

Hehn A, Fritsch C, Richards KE, Guilley H, Jonard G, 1997. Evidence for in vitro and in vivo autocatalytic processing of the primary translation product of beet necrotic yellow vein virus RNA 1 by a papain-like proteinase. Archives of Virology 142, 1051-8.

Heidel GB, Rush CM, Kendall TL, Lommel SA, French RC, 1997. Characteristics of beet soilborne mosaic virus, a furo-like virus infecting sugar beet. Plant Disease 81, 1070-6.

Huang X, Madan A, 1999. CAP3: a DNA sequence assembly program. Genome Research 9, 868-87.

Kiguchi T, Saito M, Tamada T, 1996. Nucleotide sequence analysis of RNA-5 of five isolates of beet necrotic yellow vein virus and the identity of a deletion mutant. Journal of General Virology 77, 575-80.

Kondo H, Hirano S, Chiba S, 2013. Characterization of burdock mottle virus, a novel member of the genus Benyvirus, and the identification of benyvirus-related sequences in the plant and insect genomes. Virus Research 177, 75-86.

Lau D, 2014. Trigo: viroses no ataque. Cultivar Grandes Culturas, Pelotas 15, 32-6.

Ledingham GA, 1939. Studies on Polymyxa graminis, n. gen. n. sp., a plasmodiophoraceous root parasite of wheat. Canadian Journal of Research 17, 38-51.

Lee L, Telford EB, Batten JS, Scholthof KBG, Rush CM, 2001. Complete nucleotide sequence and genome organization of Beet soilborne mosaic virus, a proposed member of the genus Benyvirus. Archives of Virology 146, 2443-53.

Legreve A, Delfosse P, Maraite H, 2002. Phylogenetic analysis of Polymyxa species based on nuclear $5.8 \mathrm{~S}$ and internal transcribed spacers ribosomal DNA sequences. Mycological Research 106, $138-47$.

Lozano I, Morales F, 2009. Molecular characterisation of Rice stripe necrosis virus as a new species of the genus Benyvirus. European Journal of Plant Pathology 124, 673-80.

Mar TB, Lau D, Schons J, Pereira PRVS, Carminatti AJ, 2013. Identification and characterization of Wheat streak mosaic virus isolates in wheat-growing areas in Brazil. International Journal of Agronomy 2013, 1-6.

Morales FJ, Ward E, Castaño M, Arroyave JA, Lozano I, Adams MJ, 1999. Emergence and partial characterization of Rice stripe necrosis virus and its fungus vector in South America. European Journal of Plant Pathology 105, 643-50.

Peltier C, Hleibieh K, Thiel H, Klein E, Bragard C, Gilmer D, 2008.

Molecular biology of the Beet necrotic yellow vein virus. Plant Viruses $2,14-24$.

Pierobom CR, Luzzardi G, Caetano VR, 1972. Ocorrência de Polymyxa graminis Led. em trigo no Rio Grande do Sul. Revista da Sociedade Brasileira de Fitopatologia 5, 1.

Poch O, Sauvaget I, Delarue M, Tordo N, 1989. Identification of four conserved motifs among the RNA dependent polymerase encoding elements. The EMBO Journal 8, 3867-74.

Roossinck MJ, Martin DP, Roumagnac P, 2015. Plant virus metagenomics: advances in virus discovery. Phytopathology 105, 716-27.

Saito M, Kiguchi T, Kusume T, Tamada T, 1996. Complete nucleotide sequence of the Japanese isolate $S$ of beet necrotic yellow vein virus RNA and comparison with European isolates. Archives of Virology 141, 2163-75.

Sela N, Luria N, Yaari M, Pruskyb D, Dombrovsky A, 2016. Genome sequence of a potential new benyvirus isolated from mango RNA-seq data. Genome Announcements 4, 1250.

Tamada T, Schmitt C, Saito M, Guilley H, Richards K, Jonard G, 1996. High resolution analysis of the read-through domain of Beet necrotic yellow vein virus read-through protein: a KTER motif is important for efficient transmission of the virus by Polymyxa betae. Journal of General Virology 77, 1359-67. 
Tamura K, Stecher G, Peterson D, Filipski A, Kumar S, 2013. MEGA6: molecular evolutionary genetics analysis version 6.0. Molecular Biology and Evolution 30, 2725-9.

Tyagi S, Sultana R, Ju H et al., 2016. The development of simple methods for the maintenance and quantification of Polymyxa graminis. Indian Journal of Microbiology 56, 482-90.

Valverde RA, Nameth ST, Jordan RL, 1990. Analysis of double-stranded RNA for plant virus diagnosis. Plant Disease 74, 255-8.

Ward E, Adams MJ, 1998. Analysis of ribosomal DNA sequences of Polymyxa species and related fungi and the development of genus and species specific primers. Mycological Research 102, 965-74.

Xu Y, Hu L, Li L et al., 2018. Ribotypes of Polymyxa graminis in wheat samples infected with Soil-borne wheat viruses in China. Plant Disease 102, 948-54.

Zerbino DR, Birney E, 2008. veLVET: algorithms for de novo short read assembly using de Bruijn graphs. Genome Research 18, 821-9.

\section{Supporting Information}

Additional Supporting Information may be found in the online version of this article at the publisher's web-site.

Figure S1. Electrophoretic analyses of the PCR products for the detection of wheat stripe mosaic virus (WhSMV) using specific primers. Products amplified using primers for detection of (a) polymerase (replicase; amplicon 464 bp), (b) TGB 2 (amplicon 607 bp). TGB 2-1, (c) RNA 1 3'-UTR (amplicon 357 bp), (d) RNA 2 3'-UTR (amplicon 329 bp) and (e) coat protein (amplicon $641 \mathrm{bp}$ ). 1: from wheat cultivar Karl 92, 2: from wheat cultivar Everest, 3: from wheat cultivar OR-1, 4: from wheat cultivar CEP11, 6: from wheat cultivars TBIO Toruk + TBIO Tibagi, 7: from wheat cultivars Esporão + LG Oro, MM: 1 kb molecular ladder, B: negative control (water).

Figure S2. Phylogenetic relationships of the family Benyviridae, based on complete genome sequences of RNA 1 (a) and RNA 2 (b). The trees were constructed by the maximum likelihood method implemented in the MEGA v. 6.0 program (Tamura et al., 2013) using the general time reversible (GTR) model with gamma distribution $(\mathrm{G})$ and bootstrap support of 6000 replications. Numbers on branches indicate bootstrap values. Alignments were performed with Muscle. Soil-borne wheat mosaic virus (SBWMV) was used as an out-group. Bar indicates the number of substitutions per site. Members of the family Benyviridae are wheat stripe mosaic virus (WhSMV), Beet necrotic yellow vein virus (BNYVV), Beet soil-borne mosaic virus (BSBMV), Burdock mottle virus (BdMV), Rice stripe necrosis virus (RSNV), and Mangifera indica latent virus (MILV).

Figure S3. Electrophoretic analyses of the PCR products for detection of wheat stripe mosaic virus (WhSMV) from wheat samples collected in different areas of Brazil, using TGB 2 primers (amplicon $607 \mathrm{bp}$ ). MM: $1 \mathrm{~kb}$ molecular ladder; $\mathrm{C}+$ : positive control (wheat TBIO Toruk cultivar with symptoms); C-: negative control (symptomless wheat TBIO Toruk cultivar); B: blank (water); 1-3: samples from Coxilha municipality (BRS Pastoreio, LG Oro and Amplitude cultivars, respectively); 4-12: samples from Ivaiporã municipality (Everest, OR 1, CEP 11, BRS Reponte, Esporão, TBIO Itaipu, TBIO Toruk, ORS 1401 and LG Oro, respectively); 13-15: samples from Santo Augusto municipality (BRS Reponte, ORS 1401 and LG Oro, respectively); 16-26: samples from Passo Fundo municipality (Everest, Karl 92, OR 1, CEP 11, BRS Reponte, Esporão, TBIO Itaipu, TBIO Toruk, ORS 1401, LG Oro and BRS Guamirim, respectively). 